\title{
THE ISSUE OF DECOSSACKIZATION IN MODERN HISTORIOGRAPHY: HISTORY OF STUDYING, LEGAL AND POLITICAL ASPECTS, BIBLIOGRAPHY AND STATISTICS OF PUBLICATIONS
}

\author{
Ivan Yu. Yurchenko \\ Russian State Agrarian University - Moscow Agricultural Academy named after K.A. Timiryazev, \\ Moscow, Russian Federation
}

\begin{abstract}
Introduction. Decossackization is a complex issue of modern historiography of the Cossacks. The scientific relevance of the decossackization issue is caused by shortage of generalizing studies. The social and political relevance is connected with the Cossack Renaissance in modern Russia. It is possible to see a major boundary in decossackization, which divided traditional and modern history of the Cossacks. Methods. The author uses the method of analytical historiography, complex, structural and comparative analysis of historiographic sources, quantitative analysis of the nomenclature of studies. The bibliography statistics is received on the Russian Science Citation Index (RSCI) database. Analysis. Defining Decossackization: definitions, approaches, periodization. Soviet and post-Soviet historiography. The newest historiography of the $21^{\text {st }}$ century. Alternative and expanded renderings of Decossackization. Approaches to how Decossackization should be determined in the legal systems of Russia and the USA. Determining Decossackization as the genocide of the Cossacks. Considering V.V. Putin and Patriarch Kirill's expressed opinions on Decossackization; the influence of these opinions on the historiography in question. Emphasizing the topicality of researching Decossackization in the historical memory of the Cossacks. Most works on Decossakization were published already in the $21^{\text {st }}$ century, but they amount to only about $1 \%$ of the whole number of studies devoted to the Cossacks, which means that new studies into the question will be both topical and necessary. Results. The scholastic research into Decossackization stems from Soviet historiography. The post-Soviet period saw a wide range of opinions and suggested approaches to the problem of Decossackization. In the $21^{\text {st }}$ century politicians, church leaders, lawyers, historians and the Cossacks themselves have reached a consensus on that Decossackization must be viewed as a tragedy. New researchers agree with the definition of Decossackization as genocide or a kind of cruel mass repression in the Soviet Russia.

Key words: Cossacks, decossackization, mass repressions, genocide of Cossacks, modern historiography, bibliography statistics, bibliography.
\end{abstract}

Citation. Yurchenko I.Yu. The Issue of Decossackization in Modern Historiography: History of Studying, Legal and Political Aspects, Bibliography and Statistics of Publications. Vestnik Volgogradskogo gosudarstvennogo universiteta. Seriya 4. Istoriya. Regionovedenie. Mezhdunarodnye otnosheniya [Science Journal of Volgograd State University. History. Area Studies. International Relations], 2019, vol. 24, no. 4, pp. 224-234. (in Russian). DOI: 


\title{
ПРОБЛЕМА РАСКАЗАЧИВАНИЯ В НОВЕЙШЕЙ ИСТОРИОГРАФИИ: ИСТОРИЯ ИЗУЧЕНИЯ, ЮРИДИЧЕСКИЕ И ПОЛИТИЧЕСКИЕ АСПЕКТЫ, БИБЛИОГРАФИЯ И СТАТИСТИКА ПУБЛИКАЦИЙ
}

\author{
Иван Юрьевич Юрченко \\ Российский государственный аграрный университет - МСХА им. К.А. Тимирязева, г. Москва, \\ Российская Федерация
}

\begin{abstract}
Аннотация. Введение. Расказачивание - сложная, комплексная проблема новейшей историографии казачества и одна из самых трагических страниц в истории казаков. Научная актуальность проблемы расказачивания вызвана дефицитом обобщающих исследований. Общественно-политическая актуальность связана с казачьим ренессансом в новейшей России. Целью исследования является анализ историографического значения расказачивания. В расказачивании можно видеть важнейший рубеж, разделивший традиционную и новейшую историю казачества. Методы. Аналитическая историография. Комплексный, структурный и сравнительный анализ историографических источников. Количественный анализ номенклатуры исследований. Библиометрия получена на базе данных РИНЦ. Анализ. Определение расказачивания: толкования, подходы, периодизация. Советская и постсоветская историография. Новейшая историография ХХІ века. Альтернативные и расширенные трактовки расказачивания. Юридические подходы к квалификации расказачивания в законодательстве России и США. Квалификация расказачивания как геноцида казаков. Рассмотрены высказывания В.В. Путина и Патриарха Кирилла о расказачивании и их влияние на историографию. Отмечена актуальность исследования расказачивания в исторической памяти казаков. Большинство научных работ по проблеме расказачивания было опубликовано уже в XXI в., однако их доля во всем массиве публикаций по казачьей проблематике составляет лишь около процента. Это определяет актуальность и востребованность новых исследований. Результаты. Научное изучение расказачивания началось еще в советской историографии. В постсоветский период наблюдается широкий спектр мнений и различных подходов к проблеме расказачивания. В XXI в. в оценках расказачивания как трагедии был достигнут консенсус политиками, церковными деятелями, юристами, историками, казаками. Новые исследователи согласны с оценкой расказачивания как геноцида казаков или жестоких массовых репрессий в Советской России.

Ключевые слова: казачество, расказачивание, массовые репрессии, геноцид казаков, новейшая историография, библиометрия, библиография.

Цитирование. Юрченко И. Ю. Проблема расказачивания в новейшей историографии: история изучения, юридические и политические аспекты, библиография и статистика публикаций // Вестник Волгоградского государственного университета. Серия 4, История. Регионоведение. Международные отношения. 2019. - T. 24, № 4. - C. 224-234. - DOI: https://doi.org/10.15688/jvolsu4.2019.4.19
\end{abstract}

Введение. Пожалуй, во всей новейшей историографии казачества нет более актуальной и болезненной (во всех смыслах) научной проблемы, чем расказачивание. Насильственно-принудительное лишение казаков не только их сословных прав и обязанностей, но и социального статуса, коллективных прав на станичную (юртовую) и войсковую собственность, изъятие (конфискация, коллективизация и т. п.) большей части личной и семейной собственности, поражение в правах, конфискация или даже намеренное убийство лошадей, в том числе обученных боевых коней, любого оружия, в том числе так называемого «дедовского оружия» (старинных шашек и других родо- вых воинских реликвий), запрет традиционных культурных практик (народного костюма, песен, танцев, джигитовки, любой казачьей атрибутики), замалчивание истории и игнорирование исторического наследия казачества, лишениежилища, принудительная депортация, наконец, проведение массового террора и репрессий в отношении не только так называемых «верхов казачества» и «врагов советской власти», но и рядовых станичников, - весь этот сложный и в высшей степени неоднозначный комплекс средств подавления и деморализации казачества, широко применявшийся советской властью в годы Гражданской войны и первые десятилетия после ее окончания, получил 
в научной литературе наименование расказачивания. Именно трагедия расказачивания отделила новейшую историю и историографию казачества XX-XXI вв. от дореволюционной традиции. Однако исследована эта проблема пока явно недостаточно. Историческому и историографическому осмыслению этой трагической страницы истории казачества в научной литературе посвящена эта статья.

Методы и материалы. Методологической основой исследования всего массива историографических источников по проблеме расказачивания является аналитическая историография, которая рассматривает весь комплекс исторических текстов как информационное сообщение, анализируемое по различным основаниям. В рамках исследования были использованы методы сравнительного и структурного анализа разнородных историографических источников, а также библиометрического анализа всего массива накопленных публикаций в фондах Российской государственной библиотеки, Научной электронной библиотеки, а также ряда других российских и зарубежных собраний.

Информационной базой проведенного количественного анализа служат исходные данные, извлеченные из НЭБ РИНЦ и обработанные с помощью аналитических инструментов надстройки РИНЦ. Таким образом, итоговая статистика построена только на публикациях, включенных в НЭБ и индексированных в РИНЦ, что дает репрезентативную выборку, в целом отражающую массив научных публикаций в рецензируемых изданиях и диссертаций за первые десятилетия XXI века. Разумеется, общий объем публикаций, как научных, так и политико-публицистических, гораздо обширнее, но в рамках поставленных задач историографического анализа выборка по РИНЦ представляется вполне достаточной.

Анализ. Рассматривая историю вопроса, сразу следует отметить, что само слово «расказачивание» официально вошло в русский литературный язык относительно недавно, после долгих лет «полуофициального» существования в качестве узкоспециального термина историков казачества и шолоховедов, и впервые появилось в толковых словарях в 1998 году. И только в 2015 г. по этой историкофилологической проблеме впервые была опуб- ликована специальная научная статья кандидата филологических наук, доцента МГГУ им. М.А. Шолохова О.А. Давыдовой [10].

В новейшей отечественной историографии проблемы расказачивания мы можем выделить несколько периодов и характерных для них исследовательских и политико-публицистических подходов. Это дореволюционная публицистика; «красная», «белая» и «самостийная» публицистика периода Великой русской революции и Гражданской войны; ранняя советская и белоэмигрантская довоенная историография; зрелая советская историография 1950-1980-х гг.; историография периода «Перестройки» в СССР; «постсоветская» и новейшая историография XXI в., главным образом российская и украинская. Из дореволюционной и советской политической публицистики наибольшее значение для историографии расказачивания имели работы В.И. Ленина (подробнее см.: [33; 39]). Внесли свой вклад в изучение вопроса и западные исследователи. Однако вплоть до 1990-х гг. западные историки и советологи были лишены доступа к первоисточникам. Расказачивание рассматривалось только в общих работах в контекстах Гражданской войны и массовых репрессий. Из новейших крупных специальных работ надо назвать монографии и статьи Питера Холквиста (см.: [35; $36]$ и др.), который обратился к изучению этой проблемы еще в своей диссертации (PhD, 1995), и Шейна О’Рурка (см.: [37; 38] и др.).

Собственно историографический анализ научной литературы по проблеме расказачивания ранее не был предметом крупных специальных исследований. В советской историографии всей казачьей тематике уделялось не слишком много внимания, по расказачиванию не было специальных работ, соответственно, не вставал вопрос и историографического анализа (см. напр.: [1; 19; 29; 31]). Проблема расказачивания рассматривалась только в общем контексте истории Гражданской войны и истории коммунистической партии (см. напр.: [2; $7 ; 15])$. Среди советских историков и историографов казачества можно назвать Л.И. Футорянского, А.И. Козлова, К.А. Хмелевского, А.П. Пронштейна, Л.А. Этенко, А.П. Ермолина, Н.Ф. Бугая, А.В. Венкова.

Однако по мере накопления историографических источников, в исторических рабо- 
тах 1990-2000-х гг. были сделаны более обстоятельные разборы историографии проблемы расказачивания. Следует назвать новые работы Л.И. Футорянского [30] и др., Н.Ф. Бугая [3; 4] и др., А.В. Венкова [6] и др., докторскую диссертацию [26] и публикации А.П. Скорика [24; 25] и др., критиковавшего его работы А.Н. Грищенко [9], кандидатскую диссертацию О.В. Кондрашенко (Рвачевой) [16], статьи Р.Г. Тикиджъяна [28] и др., А.В. Сопова [27] и др., И.Ю. Юрченко ([33; 39] и др.; также см.: [14]). Из новейших исследований важное методологическое значение имеют работы О.В. Рвачевой, обратившей особое внимание на знаковость события расказачивания и его восприятия в менталитете и народной памяти казаков как исторической трагедии, структурирующей историческое прошлое казачества (см.: $[21 ; 22 ; 23]$ и др.). В кратком историографическом обзоре А.Н. Демидова особо отметила актуальность проблемы расказачивания [11]. Гораздо более подробно она рассмотрела историографию расказачивания в приложении к истории Хоперского округа в своих кандидатской диссертации [12] и монографии [13]. В историографическом контексте можно назвать и небольшую работу П.А. Голуба [8], представившего в 2009 г. видение проблемы расказачивания с позиций современных российских неокоммунистов - своеобразный ответ на дискурс постсоветской историографии о репрессиях и реабилитации казачества. Свой собственный и весьма критический взгляд на всю советскую и постсоветскую историографию расказачивания представил в объемистой монографии Н.Н. Лысенко, который отстаивает радикально-казачьи «самостийные» позиции и оценивает расказачивание как намеренный геноцид «казацкого народа» [17]. Резкой критикой ему ответил в специальной статье А.В. Венков [5].

Во избежание недомолвок рассмотрим юридические стороны проблемы расказачивания и его оценки как намеренного геноцида. Начиная с 1991 г., когда Верховный Совет РСФСР принял закон «О реабилитации репрессированных народов», советское расказачивание стало квалифицироваться как преступная политика «клеветы и геноцида». Этот закон был принят Россией в редакции Закона
РФ от 01.07.93 № 5303-1. Статья 2-я закона прямо и недвусмысленно причислила казачество к числу репрессированных и подвергнувшихся геноциду народов России. В результате казачество стало субъектом государственно-правовых отношений и приобрело право на реабилитацию, что повлекло за собой принятие целого комплекса федеральных и региональных законов и подзаконных актов (см.: [34]). В некотором смысле этот российский закон стал своеобразным «асимметричным ответом» на известный закон США «О порабощенных нациях» 1959 г. (Public Law 86-90, или Captive Nations Week Resolution), включающим в число порабощенных «Казакию».

Из новейших публикаций юристов следует назвать фундаментальную монографию Г.Л. Москалева, который впервые рассмотрел весь комплекс проблем, связанных с правовой регламентацией понятия геноцида. Политика расказачивания в монографии однозначно отнесена «к событиям, содержащим объективные признаки геноцида» $[18$, с. 18$]$. И далее: «Под расказачиванием понимается политика террора и репрессий со стороны советской власти в отношении казачества как социальнокультурной общности в 1920-1930-е годы» [18, с. 18]. Москалев приводит многочисленные исторические факты геноцида и соответствующие прецеденты его расширительной квалификации в отношении социальных, конфессиональных, сословных, политических, субкультурных, субэтнических групп населения, как на постсоветском пространстве, так и в мировой правовой практике. По обоснованному в монографии мнению юриста, главным сущностным признаком группы, охраняемой нормой о геноциде, является культура - «отличительные культурные признаки», то есть наличие собственной уникальной культуры, традиций, знаний и навыков, которые «служат исключительно созидательным целям саморазвития и самосовершенствования общества», в отличие от «антисоциальных» преступных или экстремистских общностей [18, с. 153-154].

Здесь можно лишь добавить, что в иных публикациях о расказачивании авторы отрицают факт геноцида, видимо, не догадываясь о противоправности подобных заявлений в российской юрисдикции (или, возможно, намеренно нарушают закон, в таком случае эти 
заявления могут быть квалифицированы только как экстремистские, направленные на разжигание национальной, социальной и иной розни - см. ст. 282 УК РФ (в ред. Федерального закона от 27.12.2018 № 519-Ф3)). Хотелось бы специально отметить недопустимость использования истории расказачивания для политических спекуляций на этой действительно крайне болезненной проблеме.

Свой вклад в трактовку расказачивания, причем не только как глава государства, но и как профессиональный юрист, внес В.В. Путин в программной статье «Быть сильными: гарантия национальной безопасности России» [20]. Он определил политику расказачивания как жесточайшие репрессии и геноцид. Приведем эту часть статьи дословно: «Особо хочу сказать о казачестве. Сегодня к этому сословию себя относят миллионы наших сограждан. Исторически казаки находились на службе у Российского государства, защищали его границы, участвовали в боевых походах Русской армии. После революции 1917 г. казачество было подвергнуто жесточайшим репрессиям, по сути - геноциду. Однако казачество выжило, сохранив свою культуру и традиции. И задача государства - всячески помогать казакам, привлекать их к несению военной службы и военно-патриотическому воспитанию молодежи» [20]. Не оставил без внимания проблему расказачивания и Святейший Патриарх Московский и Всея Руси Кирилл, который обратил внимание на духовную и историко-культурную составляющую расказачивания: «атеистическая власть предприняла значительные усилия по “расказачиванию”, лишению казаков их самобытных черт, исторической памяти» (цит. по: [32, с. 21], коммент. см.: [32]).

Стоит заметить, что приведенные цитаты не только демонстрируют научную, общественную и политическую актуальность темы расказачивания, но и говорят о злободневности и значительной политизации этого вопроса в современной России и за ее пределами, что необходимо учитывать в историографическом анализе. Следует учесть и общую неясность формулировок фундаментального определения казачества как явления и исторического феномена. Например, в приведенной выше цитате В.В. Путина каза- чество фактически определено как сословие, к которому, по мысли Президента, в современной России себя «относят миллионы граждан». Это определение явно противоречит вышеприведенному закону «О реабилитации репрессированных народов» и не согласуется с данными переписей населения, но соответствует декларируемой численности Союза казаков России. Здесь очевидно мы наблюдаем смешение исторической, этнокультурной и военной составляющих понятия казачества. Напомним, что вся цитируемая статья В.В. Путина была посвящена программным вопросам военной и оборонной политики страны.

Результаты. Таким образом, вопросы содержания понятия политики расказачивания и ее периодизация, казалось бы, были однозначно определены российским и международным правом, политической практикой. Однако даже четкая юридическая квалификация и фактическая констатация расказачивания отнюдь не разрешила (и не могла разрешить) всех многочисленных научных проблем, связанных с изучением и даже простым определением исторического содержания и периодизации этого явления (социального, а также этнокультурного процесса).

К сожалению, крайне ограниченный объем данной публикации не позволяет назвать всех исследователей проблемы расказачивания в новейшей российской и зарубежной историографии и, тем более, привести полный перечень их работ. Поэтому мы вынуждены ограничиться результатами количественного анализа библиографии. В качестве исходных данных достаточно рассмотреть библиометрическую статистику РИНЦ. За последние годы была опубликована 81 работа, представленная в НЭБ РИНЦ и затрагивающая проблему расказачивания. В 79 работах, опубликованных после 2000 г., расказачивание стало одной из главных тем: в их числе 3 кандидатских и 1 докторская диссертации, 6 авторских и 1 коллективная монография, 2 сборника документов, 17 статей в сборниках научных трудов и материалах конференций, 42 статьи в журналах. В 23 работах термин «расказачивание» был вынесен в заголовок. 60 работ было опубликовано после 2010 г. (период 2011-2019 гг.). Однако при том, что 
понятие расказачивания используется более чем в тысяче статей в базе данных НЭБ, общее количество специальных исследований этой проблемы составляет менее одного процента от общего числа научных публикаций по казачьей тематике.

Количественный и качественный анализ историографии расказачивания показывает, что несмотря на появление значительного количества исследований и публикаций по проблеме расказачивания их доля в общем массиве новейшей историографии казачества остается крайне незначительной. Учитывая неоднократно отмеченные всеми исследователями актуальность и значимость этой проблемы для всей новейшей историографии казачества, особенно остро ощущается дефицит крупных специальных и обобщающих работ. Необходимы серьезные и глубокие исследования расказачивания на материалах отдельных казачьих войск (регионов) в рамках кандидатских и докторских диссертаций, а также проведение международных конференций по этой проблематике. Важным представляется и серьезное исследование глубинных паттернов исторической памяти казачества о расказачивании, их влияния на групповой менталитет казаков и индивидуальное восприятие истории.

Обсуждение результатов. Следует отметить, что обсуждение «расказачивания» как эвентуальной возможности началось еще в публицистике дореволюционной России со времени Великих реформ 1860-1870-х годов. И уже к началу XX в. четко определились противоречия в отношении сословной будущности казачества между авторами, придерживающимися консервативных, либеральных и революционно-демократических взглядов. Серьезное изучение этой «предыстории расказачивания» началось в отечественной историографии только в последние годы.

В советской историографии тема расказачивания если и не исключалась совсем из круга актуальных исторических проблем, то, во всяком случае, находилась на периферии исследовательских интересов узкого круга специалистов по истории казачества и гражданской войны на Юге России. При этом, конечно, никак нельзя утверждать, как это зачастую бывало в отечественных работах 1990-2000-х гг., что в советской науке вся про- блема расказачивания находилась под полным цензурным запретом. В специальной литературе исследовались и вопросы расказачивания, и прямо назывался «секретный» январский циркуляр Оргбюро ЦК РКП(б) (см., напр.: $[15$, с. 148$])$. В советской историографии расказачивание оценивалось однозначно как «перегибы на местах» и «намеренное вредительство», организованное скрытыми провокаторами и врагами советской власти, проникшими в среду местных руководящих кадров на Дону и на Северном Кавказе, а также троцкистами из числа командования Южфронта. В зрелых советских работах (например, в упомянутой выше монографии А.П. Ермолина) осуждаемой политике «насильственного расказачивания» всегда противопоставлялась позиция «настоящих коммунистов» на Дону и казачьего отдела ВЦИК с опорой на авторитет Ленина, осудившего подобные перегибы расказачивания в специальной телеграмме Реввоенсовету Южного фронта от 3 июня 1919 г. (см., напр.: [15, с. 148-150]).

В период «перестройки» в СССР начались процессы ревизии всей советской историографической традиции изучения проблематики Гражданской войны. Особенную политико-публицистическую остроту проблема расказачивания приобрела в контексте начавшихся в те годы процессов возрождения казачества и ренессанса казачьей культуры. Политика расказачивания была оценена как преступление коммунистического режима. Венцом этих процессов стало принятие закона РСФСР «О реабилитации репрессированных народов» (см. выше). Однако публикации этого времени имели скорее политико-публицистический, а не научный характер. Это определялось узостью источниковой базы и общим методологическим кризисом классической советской марксистской историографии в ее «истматовской редакции».

В постперестроечной историографии начала 1990-х гг. основное внимание в изучении расказачивания было уделено введению в научный оборот новооткрытых источников из рассекреченных архивных фондов и заполнению «белых пятен» в истории Гражданской войны в казачьих областях. Существенное влияние на отечественную историографию в этот период оказала западная и эмигрантская 
историография, доступ к которой в советское время был существенно ограничен. В результате для работ 1990-х - начала 2000-х гг. зачастую было свойственно некритическое заимствование готовых западных моделей и подходов. На новой методологической и широкой источниковой базе новейшая историография смогла по-новому взглянуть на расказачивание уже в новом столетии. Причем, как было отмечено выше, большинство работ вышло уже во втором десятилетии XXI века. Эта, новейшая, историографическая ситуация способствовала появлению широкого спектра мнений и различных подходов к исследованию проблемы расказачивания, что, в свою очередь, спровоцировало оживленные дискуссии историков и других специалистов о содержании, исторической сущности, квалификации и периодизации расказачивания как исторического явления, политического, социального и этнокультурного процесса. Однако можно считать, что в настоящее время найден консенсус ученых и политиков в моральной оценке расказачивания как наиболее трагической страницы казачьей истории.

В данной работе, конечно, не претендуя на полноту изложения, ограниченного рамками одной статьи, мы ограничились тем, что бегло очертили круг историографических источников и рассмотрели привходящие юридические и общественно-политические мотивы актуализации проблемы расказачивания, которые способны оказывать непосредственное влияние на исторические оценки и подходы к проблеме. В заключение остается лишь добавить, что автор надеется вернуться к этой актуальной теме в последующих публикациях, посвященных подробному историографическому анализу новейших подходов к исследованию расказачивания.

\section{СПИСОК ЛИТЕРАТУРЫ}

1. Актуальные вопросы историографии Октября на Дону и Северном Кавказе : [сб. ст.] / отв. ред. А. И. Козлов. - Ростов н/Д : Изд-во Рост. ун-та, 1986. $-138 \mathrm{c}$.

2. Берз, Л. И. Героические годы. Октябрьская революция и гражданская война на Дону : Исторический очерк / Л. И. Берз, К. А. Хмелевский. - Ростов н/Д : Рост. кн. изд-во, 1964. -342 c.
3. Бугай, Н. Ф. Проблемы истории казачества Юга России в историографии: советский и российский аспекты / Н. Ф. Бугай // История и историки : историографический вестник, 2013-2014 / Институт российской истории РАН. - М. : ИРИ РАН, 2015. - C. 11-139.

4. Бугай, Н. Ф. Проблемы репрессий и реабилитации граждан: история и историография (XX в. - начало XXI в.) / Н. Ф. Бугай. - М. : Гриф и К, 2012. $-479 \mathrm{c}$.

5. Венков, А. В. Геноцид, голодомор и другие ужасы в истории «казацкого народа» / А. В. Венков // Новое прошлое = The New Past. -2018 . - № 1. C. 275-290.-DOI: 10.23683/2500-3224-2018-1-275-290.

6. Венков, А. В. Донское казачество в гражданской войне (1918-1920) / А. В. Венков. - Ростов н/Д : Изд-во Ростов. ун-та. $-1992 .-128$ с.

7. Венков, А. В. Донское казачество в гражданской войне : автореф. дис. ... канд. ист. наук : 07.00.02 / Венков Андрей Вадимович. - Ростов н/Д, 1986. - 24 с.

8. Голуб, П. А. Правда и ложь о «расказачивании» казаков / П. А. Голуб. - М. : [б. и.], 2009. -142 с.

9. Грищенко, А. Н. О советском прошлом казачества Юга России: странности современной историографической ситуации (Рец. на кн.: Скорик, А. П. Многоликость казачества Юга России в 1930-е годы : очерки истории. - Ростов н/Д : Изд-во СКНЦ ВШ ЮФУ, 2008. -344 с.; Скорик, А. П. Казачий Юг России в 1930-е годы: грани исторических судеб социальной общности. - Ростов н/Д : Изд-во СКНЦ ВШ ЮФУ, 2009. -508 с.) / А. Н. Грищенко // Новый исторический вестник. - 2012. № 2 (32). - C. 126-130.

10. Давыдова, О. А. Страшное слово расказачивание / О. А. Давыдова // Вестник Российского нового университета. Серия: Человек в современном мире. - 2015. - № 2. - С. 16-21.

11. Демидова, А. Н. Актуальные проблемы изучения советского периода истории донского казачества / А. Н. Демидова // Стратегические ориентиры инновационного развития АПК в современных экономических условиях : материалы Междунар. науч.-практ. конф. - Волгоград : ВолгГАУ, 2016. - C. 74-80.

12. Демидова, А. Н. Расказачивание в Хоперском округе в 1918-1931 гг. : дис. канд. ист. наук : 07.00.02 / Демидова Анна Николаевна. - Волгоград, 2002. $-186 \mathrm{c}$.

13. Демидова, А. Н. Расказачивание в Хоперском округе в 1918-1931 гг. : [монография] / А. Н. Демидова. - Волгоград : Изд-во Волгогр. ГАУ, 2013. - 232 с.

14. Дунаева, Ю. В. 2015.01.006. Юрченко И. Ю. Историография казачества : в 2 кн. - М. : Моск. гос. ун-т природообустройства, 2013. - Кн. 1: История изучения казачества в отечественной и эмигрантской историографии XV-XX столетий. -455 c. - Биб- 
лиогр.: с. 393-454 ; Кн. 2: Изучение казачества в новейшей отечественной историографии, 19812012 гг.-474 с. - Библиогр.: с. 177-440 / Ю. В. Дунаева, И. Ю. Юрченко // Социальные и гуманитарные науки. Отечественная и зарубежная литература. Серия 5, История. Реферативный журнал. - 2015. № 1. - С. 44- 49 .

15. Ермолин, А. П. Революция и казачество: (1917-1920 гг.) : [монография] / А. П. Ермолин. М. : Мысль, 1982. - 224 с.

16. Кондрашенко, О.В.Войско Донское и процессы возрождения российской государственности на Юге России в период Гражданской войны, 1917 нач. 1920 гг. : дис. ... канд. ист. наук : 07.00.02 / Кондрашенко [Рвачева] Ольга Владимировна. - Волгоград, 2001. $-281 \mathrm{c}$.

17. Лысенко, Н. Н. Геноцид казаков в Советской России и СССР: 1918-1933 гг. : Опыт этнополитического исследования : [монография] / Н. Н. Лысенко. - Ростов н/Д : Альтаир, 2017. - 636 с.

18. Москалев, Г. Л. Уголовная ответственность за геноцид : (Ст. 357 УК РФ) / Г. Л. Москалев. - Красноярск : Сиб. федеральный ун-т, 2017. - 188 с.

19. Пронштейн, А. П. Донское казачество в советской историографии / А. П. Пронштейн, К. А. Хмелевский // Вопросы истории. - 1965. № 1. - С. 137-146.

20. Путин, В. В. Быть сильными: гарантия национальной безопасности России / В. В. Путин // Российская газета : Столичный выпуск. - 2012. 20 февр. (№ 5708 (35)). - № 35.

21. Рвачева, О. В. Движение за возрождение казачества на Юге России в начале 1990-х гг.: организационные формы, идеи и участники процесса / О. В. Рвачева // Вестник Волгоградского государственного университета. Серия 4, История. Регионоведение. Международные отношения. - 2016. T. 21, № 4. - C. 124-134. - DOI: https://doi.org/10. 15688/jvolsu4.2016.4.13.

22. Рвачева, О. В. Социальная память и история. Попытки методологического анализа казачьего возрождения / О. В Рвачева // Проблемы истории, филологии, культуры. - 2013. - № 3 (41). C. $374-380$.

23. Рвачева, О. В. Трагические события XX века и коллективная память казачества: постановка проблемы / О. В. Рвачева // Политическое пространство и социальное время: идентичность и повседневность в структуре жизненного мира : XXX Харакский форум, 26-30 мая 2016 г., г. Ялта, Республика Крым : тезисы / гл. ред.: Т. А. Сенюшкина, А. В. Баранов. Симферополь : Ариал, 2016. -С. 158-162.

24. Скорик, А. П. Расказачивание на Юге России в 1930-х гг.: исторические мифы и реальность / А. П. Скорик, В. А. Бондарев // Отечественная история. - 2008. - № 5. - С. 97-108.
25. Скорик, А. П. Заметки о книгах: Кислицын С.А. Государство и расказачивание $1917-$ 1945 гг. : учебное пособие по спецкурсу. Ростов н/Д, 1996. 80 с. / А. П. Скорик, Р. Г. Тикиджьян // Известия высших учебных заведений. Северо-Кавказский регион. Серия: Общественные науки. - 1998. - № 1. С. 92-94.

26. Скорик, А. П. Казачество Юга России в 30-е годы ХХ века: исторические коллизии и опыт преобразований : дис. ... д-ра ист. наук : 07.00.02 / Скорик Александр Павлович. - Ставрополь, 2009. - 540 с.

27. Сопов, А. В. Расказачивание: факты и смыслы / А. В. Сопов // Вопросы казачьей истории и культуры: материалы XXII Регионального фестиваля казачьей культуры. Вып. 9 / ред.-сост.: М. Е. Галецкой, Н. Н. Денисова, Г. Б. Луганская. - Майкоп : Магарин О.Г., 2013. - С. 239-248.

28. Тикиджьян, Р. Г. Донская казачья государственность и истоки политики «советского расказачивания» 1918-1920 гг. : Продолжение известной дискуссии / Р. Г. Тикиджьян // Казачья государственность: исторические, правовые и культурные аспекты : сб. ст. 2-й Междунар. электрон. науч. конф. / под ред. С. М. Сивкова. - Краснодар : Южный ин-т менеджмента, 2014. - С. 209-221.

29. Футорянский, Л. И. Казачество в период Октября и гражданской войны в советской историографии / Л. И. Футорянский. - М. : Ин-т истории СССР АН СССР, 1969. - 30 c.

30. Футорянский, Л. И. Казачество России в Гражданской войне (1918-1920 гг.) : Историография и источники изучения проблемы / Л. И. Футорянский. - Оренбург : Пресса, 2001. - 41 с.

31. Хмелевский, К. А. Современная советская историография борьбы за власть Советов на Дону и Северном Кавказе / К. А Хмелевский, Л. А. Этенко // История и историки: историографический ежегодник. 1977 / отв. ред. М. В. Нечкина. - М. : Наука, 1980. - С. 28-38.

32. Чайкин, Т. К. Символизм изгнания донских казаков в контексте большевистской политики расказачивания / Т. К. Чайкин // Архонт. - 2019. № 1 (10). - С. 21-25.

33. Юрченко, И. Ю. «Аграрная программа социал-демократии в первой русской революции 1905-1907 годов» В. И. Ленина как методологическая основа политики расказачивания и ее трактовки в советской историографии / И. Ю. Юрченко // В мире научных открытий. - 2011. - № 11.5. C. $1516-1532$.

34. Юрченко, И. Ю. Казачий ренессанс на Кавказе в начале 90-х годов 20 века и его отражение в юридических источниках (федеральные законы и акты) / И. Ю. Юрченко // Культурная жизнь Юга России. - 2012. - № 4 (47). - С. 94-98. 
35. Holquist, P. "Conduct merciless mass terror": decossackization on the Don, 1919 / P. Holquist // Cahiers du Monde Russe. - 1997. - Vol. 38, № 1-2. P. 127-162.

36. Holquist, P. Making War, Forging Revolution: Russia's Continuum ofCrisis, 1914-1921 / P. Holquist. Cambridge : Harvard University Press, 2002. - 359 p.

37. O'Rourke, S. The Cossacks / S. O'Rourke. Manchester : Manchester University Press, 2007.-302 p.

38. O'Rourke, S. Trial Run: The Deportation of the Terek Cossacks 1920 / S. O'Rourke // Removing Peoples: Forced Removal in the Modern World. Oxford : Oxford University Press, 2009. - P. 255-277.

39. Yurchenko, I. Yu. "The Agrarian Program of Social Democracy in the First Russian Revolution Of 1905-1907" of V. I. Lenin as a methodological base of Policy of Dispossession of the Cossacks and its Interpretations in the Soviet Historiography / I. Yu. Yurchenko// In the World of Scientific Discoveries. Series A. - 2013. - Vol. 1, No. 2. - P. 131-144.

\section{REFERENCES}

1. Kozlov A.I., ed. Aktualnye voprosy istoriografii Oktyabrya na Donu $i$ Severnom Kavkaze: [sb. st.] [Relevant Issues of the Historiography of the October on the Don and North Caucasus. Collected Articles]. Rostov-on-Don, Izd-vo Rostovskogo universiteta, 1986. 138 p.

2. Berz L.I., Khmelevskiy K.A. Geroicheskie gody. Oktyabrskaya revolyutsiya i grazhdanskaya voyna na Donu: Istoricheskiy ocherk [Heroic Time. October Revolution and the Civil War on the Don. Historical Sketch]. Rostov-on-Don, Rostovskoe knizhnoe izdatelstvo, 1964. 342 p.

3. Bugay N.F. Problemy istorii kazachestva Yuga Rossii v istoriografii: sovetskiy i rossiyskiy aspekty [Problems of the History of the Cossacks of the South of Russia in Historiography. Soviet and Russian Aspects]. Istoriya $i$ istoriki: istoriograficheskiy vestnik, 2015, vol. 2013-2014, pp. 11-139.

4. Bugay N.F. Problemy repressiy i reabilitatsii grazhdan: istoriya i istoriografiya ( $X X v$. - nachalo $X X I$ v.) [Problems of Repressions and Rehabilitation of Citizens. History and Historiography $\left(20^{\text {th }}-\right.$ Early $21^{\text {st }}$ c.)]. Moscow, Grif i K Publ., 2012. 479 p.

5. Venkov A.V. Genotsid, golodomor i drugie uzhasy v istorii «kazatskogo naroda» [Genocide, Holodomor and Other Horrors in the History of the "Cossack people"]. Novoe proshloe [The New Past], 2018, no. 1, pp. 275-290. doi: 10.23683/2500-3224-2018$1-275-290$.

6. Venkov A.V. Donskoe kazachestvo v grazhdanskoy voyne (1918-1920) [The Don Cossacks in the Civil War (1918-1920)]. Rostov-
on-Don, Izdatelstvo Rostovskogo universiteta, 1992. $128 \mathrm{p}$.

7. Venkov A.V. Donskoe kazachestvo v grazhdanskoy voyne: avtoref. dis. ... kand. ist. nauk [The Don Cossacks in the Civil War. Cand. hist. sci. abs. diss.]. Rostov-on-Don, 1986. 24 p.

8. Golub P.A. Pravda i lozh o "raskazachivanii»" kazakov [Truth and Lie About "Decossackization" of Cossacks]. Moscow, 2009. 142 p.

9. Grishchenko A.N. O sovetskom proshlom kazachestva Yuga Rossii: strannosti sovremennoy istoriograficheskoy situatsii (Rets. na kn.: Skorik, A.P. Mnogolikost kazachestva Yuga Rossii v 1930-e gody: ocherki istorii. - Rostov n/D: Izd-vo SKNTs VSh YuFU, 2008. - 344 s.; Skorik, A.P. Kazachiy Yug Rossii v 1930-e gody: grani istoricheskikh sudeb sotsialnoy obshchnosti. - Rostov n/D: Izd-vo SKNTs VSh YuFU, 2009. - 508 s.) [On the Soviet Past of the South Russian Cossacks. The Oddities of the Modern Historiographic Situation (Book Review: Skorik A.P. The Multiplicity of the Cossacks of the South of Russia in the 1930s. Historical Essays. Rostov-on-Don, Izd-vo SKNTs VSh YuFU, 2008. 344 p.; Skorik A.P. Cossack South of Russia in the 1930s. On the Frontier of Historical Destinies of Social Community. Rostovon-Don, Izd-vo SKNTs VSh YuFU, 2009. 508 p.)]. Novyy istoricheskiy vestnik [The New Historical Bulletin], 2012, no. 2 (32), pp. 126-130.

10. Davydova O.A. Strashnoe slovo raskazachivanie [Terrible Word "Decossackization"]. Vestnik Rossiyskogo novogo universiteta. Seriya: Chelovek v sovremennom mire [Vestnik of Russian New University. Man in the Modern World], 2015, no. 2, pp. 16-21.

11. Demidova A.N. Aktualnye problemy izucheniya sovetskogo perioda istorii donskogo kazachestva [Current Problems of Studying the Soviet Period of the Don Cossack History]. Strategicheskie orientiry innovatsionnogo razvitiya APK v sovremennykh ekonomicheskikh usloviyakh: materialy Mezhdunar. nauch.-prakt. konf [Strategic Reference Points of Innovative Development of Agrarian and Industrial Complex in Modern Economic Conditions. Proceedings of the International Scientific and Practical Conference]. Volgograd, VolgGAU, 2016, pp. 74-80.

12. Demidova A.N. Raskazachivanie $v$ Khoperskom okruge v 1918-1931 gg.: dis. kand. ist. nauk [Decossackization in Khoper District in 19181931. Cand. hist. sci. diss.]. Volgograd, 2002. 186 p.

13. Demidova A.N. Raskazachivanie $v$ Khoperskom okruge v 1918-1931 gg.: [monografiya] [Decossackization in Khoper District in 1918-1931. Monograph]. Volgograd, Volgogradskogo GAU, 2013. $232 \mathrm{p}$.

14. Dunaeva Yu.V. Yurchenko I.Yu. Istoriografiya kazachestva: v 2 kn. - M.: Mosk. gos. un-t 
prirodoobustroystva, 2013. - Kn. 1: Istoriya izucheniya kazachestva $\mathrm{v}$ otechestvennoy i emigrantskoy istoriografii XV-XX stoletiy. - 455 s. - Bibliogr.: s. 393454; Kn. 2: Izuchenie kazachestva $\mathrm{v}$ noveyshey otechestvennoy istoriografii, 1981-2012 gg. - 474 s. Bibliogr.: s. 177-440 [Historiography of the Cossacks. In 2 Books. Moscow, Moskovskiy gosudarstvennyy universitet prirodoobustroystva, 2013. Book 1. History of Studying the Cossacks in Domestic and Emigrant Historiography of the $15^{\text {th }}-20^{\text {th }}$ Centuries. $455 \mathrm{p}$. Bibliography, pp. 393-454. Book 2. Studying the Cossacks in Modern Domestic Historiography, 19812012. 474 p. Bibliography, pp. 177-440]. Sotsialnye $i$ gumanitarnye nauki. Otechestvennaya $i$ zarubezhnaya literatura. Seriya 5, Istoriya. Referativnyy zhurnal, 2015, no. 1, pp. 44-49.

15. Ermolin A.P. Revolyutsiya i kazachestvo: (1917-1920 gg.): [monografiya] [Revolution and the Cossacks. (1917-1920). Monograph]. Moscow, Mysl Publ., 1982. 224 p.

16. Kondrashenko O.V. Voysko Donskoe $i$ protsessy vozrozhdeniya rossiyskoy gosudarstvennosti na Yuge Rossii v period Grazhdanskoy voyny, 1917 nach. 1920 gg.: dis. ... kand. ist. nauk [The Don Cossack Host and Processes of the Russian Statehood Revival in the South of Russia During the Civil War, 1917 Early 1920. Cand. hist. sci. diss.]. Volgograd, 2001.281 p.

17. Lysenko N.N. Genotsid kazakov v Sovetskoy Rossii i SSSR: 1918-1933 gg.: Opyt etnopoliticheskogo issledovaniya: [monografiya]. [Genocide of Cossacks in the Soviet Russia and USSR. 1918-1933. Experience of Ethnopolitical Research. Monograph]. Rostov-on-Don, Altair Publ., 2017.636 p.

18. Moskalev G.L. Ugolovnaya otvetstvennost za genotsid: (St. $357 U K R F$ ) [Criminal Liability for Genocide. (Article 357 of the Criminal Code of the Russian Federation)]. Krasnoyarsk, Sibirskiy federalnyy universitet, 2017. $188 \mathrm{p}$.

19. Pronshtein A.P., Khmelevskiy K.A. Donskoe kazachestvo v sovetskoy istoriografii [The Don Cossacks in the Soviet Historiography]. Voprosy istorii, 1965, no. 1, pp. 137-146.

20. Putin V.V. Byt silnymi: garantiya natsionalnoy bezopasnosti Rossii [To be Strong. Guarantee of the National Security of Russia]. Rossiyskaya gazeta: Stolichnyy vypusk, 2012, February 20, (no. 5708 (35)), no. 35 .

21. Rvacheva O.V. Dvizhenie za vozrozhdenie kazachestva na Yuge Rossii v nachale 1990-kh gg.: organizatsionnye formy, idei i uchastniki protsessa [Movement for Revival of the Cossacks in the South of Russia in the Early 1990s. Organizational Forms, Ideas and Participants of the Process]. Vestnik Volgogradskogo gosudarstvennogo universiteta. Seriya 4. Istoriya. Regionovedenie. Mezhdunarodnye otnosheniya [Science Journal of Volgograd State
University. History. Area Studies. International Relations], 2016, vol. 21, no. 4, pp. 124-134. doi: https:// doi.org/10.15688/jvolsu4.2016.4.13

22. Rvacheva O.V. Sotsialnaya pamyat $\mathrm{i}$ istoriya. Popytki metodologicheskogo analiza kazachyego vozrozhdeniya [Social Memory and History. Attempts of the Methodological Analysis of the Cossack Revival]. Problemy istorii, filologii, kultury [Journal of Historical, Philological and Cultural Studies], 2013, no. 3 (41), pp. 374-380.

23. Rvacheva O.V. Tragicheskie sobytiya XX veka i kollektivnaya pamyat kazachestva: postanovka problemy [Tragic Events of the $20^{\text {th }}$ Century and Collective Memory of the Cossacks. Problem Statement]. Senyushkina T.A., ed. Politicheskoe prostranstvo $i$ sotsialnoe vremya: identichnost $i$ povsednevnost $v$ strukture zhiznennogo mira:: XXX Kharakskiy forum, 26-30 maya 2016 g., g. Yalta, Respublika Krym: tezisy [Political Space and Social Time. Identity and Everyday Life in the Structure of the Life World. 30 ${ }^{\text {th }}$ Kharakskiy Forum, May 26-30, 2016, Yalta, Republic of Crimea. Collection of Theses]. Simferopol, Arial Publ., 2016, pp. 158-162.

24. Skorik A.P., Bondarev V.A. Raskazachivanie na Yuge Rossii v 1930-kh gg.: istoricheskie mify i realnost [Decossackization in the South of Russia in the 1930s. Historical Myths and Reality]. Otechestvennaya istoriya, 2008, no. 5, pp. 97-108.

25. SkorikA.P., Tikidzhyan R.G. Zametki o knigakh: Kislitsyn S.A. Gosudarstvo i raskazachivanie 19171945 gg.: Uchebnoe posobie po spetskursu. Rostovon-Don, 1996. 80 s. [Notes on Books: Kislitsyn S.A. State and Decossackization of 1917-1945. Study Guide on the Special Course. Rostov-on-Don, 1996. 80 p.]. Izvestiya vysshikh uchebnykh zavedeniy. SeveroKavkazskiy region. Seriya: Obshchestvennye naukis [University News. North-Caucasian Region. Social Sciences Series], 1998, no. 1, pp. 92-94.

26. SkorikA.P. Kazachestvo Yuga Rossii v 30-e gody XX veka: istoricheskie kollizii i opyt preobrazovaniy: dis. ... d-ra ist. nauk [The Cossacks of the South of Russia in the $30 \mathrm{~s}$ of the $20^{\text {th }}$ Century. Historical Collisions and Experience of Transformations. Dr. hist. sci. diss.]. Stavropol, 2009. 540 p.

27. Sopov A.V. Raskazachivanie: fakty i smysly [Decossackization. Facts and Meanings]. Galetskoy M.E., Denisova N.N., Luganskaya G.B., eds. Voprosy kazachyey istorii $i$ kultury: materialy XXII Regionalnogo festivalya kazachyey kultury [Issues of Cossack History and Culture. Proceedings of the $22^{\text {nd }}$ Regional Festival of Cossack Culture]. Maykop, Magarin O.G. Publ., 2013, iss. 9, pp. 239-248.

28. Tikidzhyan R.G. Donskaya kazachya gosudarstvennost i istoki politiki «sovetskogo raskazachivaniya»1918-1920 gg.: Prodolzhenie izvestnoy diskussii [Don Cossack Statehood and 
Sources of "Soviet Decossackization" Policy of 1918-1920. Continuation of the Famous Discussion]. Sivkov S.M., ed. Kazachya gosudarstvennost: istoricheskie, pravovye i kulturnye aspekty: sb. st. 2-y Mezhdunar. el. nauch. konf. [Cossack Statehood. Historical, Legal and Cultural Aspects. Collection of Articles of the $2^{\text {nd }}$ International Electronic Scientific Conference]. Krasnodar, Yuzhnyy institut menedzhmenta, 2014, pp. 209-221.

29. Futoryanskiy L.I. Kazachestvo $v$ period Oktyabrya i grazhdanskoy voyny $v$ sovetskoy istoriografii [The Cossacks During the October and Civil War in the Soviet Historiography]. Moscow, Institut istorii SSSR AN SSSR, 1969. 30 p.

30. Futoryanskiy L.I. Kazachestvo Rossii v Grazhdanskoy voyne (1918-1920 gg.): Istoriografiya $i$ istochniki izucheniya problemy [The Cossacks of Russia in the Civil War(1918-1920). Historiography and Sources of Problem Studying]. Orenburg, Pressa Publ., 2001.41 p.

31. KhmelevskiyK.A., Etenko L.A. Sovremennaya sovetskaya istoriografiya borby za vlast Sovetov na Donu i Severnom Kavkaze [Modern Soviet Historiography of the Race for Power of the Soviets on the Don and North Caucasus]. Nechkina, ed. Istoriya $i$ istoriki: istoriograficheskiy ezhegodnik. 1977, 1980, pp. 28-38.

32. Chaykin T.K. Simvolizm izgnaniya donskikh kazakov v kontekste bolshevistskoy politiki raskazachivaniya [Symbolism of the Exile of Don Cossacks in the Context of the Bolshevist Policy of Decossackization]. Arkhont, 2019, no. 1 (10), pp. 21-25.

33. Yurchenko I.Yu. «Agrarnaya programma sotsial-demokratii v pervoy russkoy revolyutsii 1905 1907 godov» V.I. Lenina kak metodologicheskaya osnova politiki raskazachivaniya i ee traktovki v sovetskoy istoriografii ["The Agrarian Program of Social Democracy in the First Russian Revolution of 1905-1907" of V.I. Lenin as a Methodological Base of Policy of Dispossession of the Cossacks and Its Interpretations in Soviet Historiography]. $V$ mire nauchnykh otkrytiy [Siberian Journal of Life Sciences and Agriculture], 2011, no. 11.5, pp. 1516-1532.

34. Yurchenko I.Yu. Kazachiy renessans na Kavkaze v nachale $90-\mathrm{kh}$ godov 20 veka i ego otrazhenie v yuridicheskikh istochnikakh (federalnye zakony i akty) [Cossack Renaissance in the Caucasus in the Early 90 s of the $20^{\text {th }}$ Century and Its Reflection in Legal Sources (Federal Laws and Acts)]. Kulturnaya zhizn Yuga Rossii [Cultural Studies Russian South], 2012, no. 4 (47), pp. 94-98.

35. Holquist P. "Conduct Merciless Mass Terror": Decossackization on the Don, 1919. Cahiers du Monde Russe, 1997, vol. 38, no. 1-2, pp. 127-162.

36. Holquist P. Making War, Forging Revolution: Russia's Continuum of Crisis, 1914-1921. Cambridge, Harvard University Press, 2002. 359 p.

37. O'Rourke S. The Cossacks. Manchester, Manchester University Press, 2007. 302 p.

38. O'Rourke S. Trial Run: The Deportation of the Terek Cossacks 1920. Removing Peoples: Forced Removal in the Modern World. Oxford, Oxford University Press, 2009, pp. 255-277.

39. Yurchenko I.Yu. "The Agrarian Program of Social Democracy in the First Russian Revolution of 1905-1907" of V.I. Lenin as a Methodological Base of Policy of Dispossession of the Cossacks and Its Interpretations in the Soviet Historiography. World of Scientific Discoveries, Series A, 2013, vol. 1, no. 2, pp. 131-144.

\section{Information about the Author}

Ivan Yu. Yurchenko, Candidate of Sciences (History), Associate Professor, Independent Researcher, Technical Editor of "Vestnik SMC" Scientific Journal, Russian State Agrarian University Moscow Agricultural Academy named after K.A. Timiryazev, Timiryazevskaya St., 49, 127550 Moscow, Russian Federation, ivankazzak@mail.ru, https://orcid.org/0000-0002-7959-2891

\section{Информация об авторе}

Иван Юрьевич Юрченко, кандидат исторических наук, доцент, независимый исследователь, технический редактор научного журнала «Вестник НМС», Российский государственный аграрный университет - МСXА им. К.А. Тимирязева, ул. Тимирязевская, 49, 127550 г. Москва, Российская Федерация, ivankazzak@mail.ru, https://orcid.org/0000-0002-7959-2891 